\title{
HABITAT MANIPULATION FOR LUCERNE: A RENAISSANCE FOR STRIP-CUTTING?
}

\author{
Z. HOSSAIN ${ }^{1}$, G.M. GURR ${ }^{1}$ and S.D. WRATTEN ${ }^{2}$ \\ ${ }^{1}$ Orange Agricultural College, University of Sydney, P O Box 883, Orange, NSW, Australia \\ ${ }^{2}$ Department of Entomology and Animal Ecology, Lincoln University, P O Box 84, \\ Canterbury, New Zealand
}

Strip-cutting was evaluated as a habitat manipulation approach to pest management in lucerne (Medicago sativa $\mathrm{L}$ ). In a field experiment with linear replication, $20 \mathrm{~m}$ long strips were left uncut at each harvest to provide nectar, pollen and shelter. Sweep net and vacuum sampling were used to determine arthropod densities in the period after harvests. Predatory coccinellids (Micraspis frenata, Coccinella repanda and Diomus notescens) were significantly more numerous in uncut lucerne strips than in cut control areas in all three samples (December, January and February). Uncut strips also harboured significantly greater numbers of two predatory hemipterans (Nabis sp. and Oechalia schellembergii) in the first sample date, and of two unidentified hymenopterans in the last sample. In contrast, numbers of Helicoverpa spp. larvae and aphids were consistently greater in cut areas. We conclude that uncut lucerne strips provide important resources for several guilds of natural enemies and that this can lead to reduced populations of at least two key pests. However, on some sample dates the uncut strips harboured greater numbers of several potential pests (green mirid, Creontiades dilutus, and green vegetable bug Nezara viridula) so further work is required to determine the net effect on crop loss.

\section{FIELD-SCALE HABITAT MANIPULATION FOR THE BIOLOGICAL CONTROL OF POTATO MOTH BY COPIDOSOMA KOEHLERI}

\author{
L.R. BAGGEN and G.M. GURR
}

\section{Orange Agricultural College, The University of Sydney, Orange NSW 2800, Australia}

We report results from a field-scale habitat manipulation trial in which the nectar producing herb borage (Borago officinalis L.) was sown in the margin of a commercial potato crop. Weekly leaf and vacuum samples were used to determine the effects of this food resource on the pest, potato moth (Phthorimaea operculella (Zeller)), and its parasite Copidosoma koehleri Blanchard. During the period from February-March C. koehleri adults remained most abundant close to the flowering borage strip, whereas potato moth adults became distributed uniformly within the crop. No evidence was found of potato moth adults feeding on borage nectar. Larvae of potato moth recovered from the crop ca. $5 \mathrm{~m}$ from borage plants were more heavily parasitised $(62.35 \%)$ than larvae from the crop interior or from the opposite crop edge (16.21\%), ca. $130 \mathrm{~m}$ from the borage. These results indicate that nectar from borage border plantings provides a selective benefit to $C$. koehleri and that this approach to conservation biological control can increase the impact of classical biological control on pests. 